\title{
Cacao roasting in rural areas of Peru using concentrated solar thermal energy: experimental results
}

\author{
François Veynandt ${ }^{1, *}$, Juan Pablo Perez Panduro ${ }^{1}$, Jorge Elías Soria Navarro ${ }^{1}$, and Miguel Hadzich ${ }^{1,2}$ \\ ${ }^{1}$ Grupo de Apoyo al Sector Rural, Pontificía Universidad Católica del Perú (GRUPO PUCP), Lima, Peru \\ 2 Department of Mechanical Engineering, Pontificía Universidad Católica del Perú (PUCP), Lima, Peru
}

\begin{abstract}
Solar food processing is gaining interest for income generation. Our solar cacao roaster, designed for rural areas, consists in a horizontal rotating drum, opened at one end to collect solar radiation from Scheffler concentrators of 2.7 or $8 \mathrm{~m}^{2}$. The experimental results presented bring knowledge on the system's behavior and optimal operation. The influence of the most significant parameters is studied: quantity of cacao, absorptivity of drum's coating, thermal insulation, inclination and rotational speed of the drum. Cacao temperature and direct solar irradiance are monitored to evaluate the performance in roasting time per kilogram of cacao.
\end{abstract}

\section{Introduction}

There are a couple of experiences on solar roasting. Solar Roast Coffee, in USA, originally used concentrating solar thermal energy to roast coffee [1]. ChocoBiciSolar produces chocolate using solar and bicycle-powered machines. Started in 2004 as Chocosol, several $100 \mathrm{~kg}$ of cacao have been roasted per year with a technology based on the solar concentrator now diffused by GoSol [2]. In Namibia, Nailoke Solar House roasts peanuts in a solar box cooker. The roast is more homogeneous than with the traditional coal or wood fire. In Burkina Faso, ULOG Freiburg and ISOMET developed a solar powered shea butter production unit. The roasting step is performed in a pot. Constant manual stirring with a wooden paddle ensures an even roast of the shea nuts [3].

Cacao is an important agricultural product in Peru. An appropriated solar technology to process cacao beans at the small growers scale can improve the local economy and their quality of life.

The technology proposed uses a rotating drum heated by concentrated solar thermal energy. Designed for the rural sector, it is robust, low tech, low cost, based on Scheffler open-source solar concentrator $[4,5]$. The aim is achieving the highest quality of cacao with a technology both environmentally and socially responsible.

\section{Experimental work}

\subsection{Pilot plant and solar resource}

The experiments have been performed in November 2014 on the pilot solar production unit of pure cacao paste in Huyro, region of Cusco, Peru. The solar roasting technology

\footnotetext{
* e-mail: francois.veynandt@gmail.com
}

with its main elements is presented on Figure 1. Twenty experiments of solar roasting have been realized: eight on a large Scheffler concentrator of $8 \mathrm{~m}^{2}$ mirror surface and 12 on a small one of $2.7 \mathrm{~m}^{2}$.

The annual average Direct Normal Irradiance (DNI) is $5.59 \mathrm{kWh} /\left(\mathrm{m}^{2} /\right.$ day) at the test field in Huyro (latitude $-13.01^{\circ}$; longitude $-72.56^{\circ}$ ) according to NASA database [6]. The cacao harvest season is mainly from April to September, but roasting can be performed all year round. Most of the experiments are performed between 8:30 a.m. and $3: 30 \mathrm{p} . \mathrm{m}$., with direct solar irradiance usually above $700 \mathrm{~W} / \mathrm{m}^{2}$.

\subsection{Operation of the roaster, procedure of the experiment}

The use of sunglasses and thermal gloves is required. Each experiment consists in the following steps:

Preheating the empty drum to at least $120{ }^{\circ} \mathrm{C}$.

Feeding cacao beans in the rotating drum.

Roasting cacao beans: by direct exposure to concentrated sunlight, the beans heat up to a temperature of 120 to $160{ }^{\circ} \mathrm{C}$.

Extracting cacao beans from the drum.

Husking and grinding to obtain pure cacao paste.

\subsection{Measurements}

DNI $I_{\text {direct }}$ is measured with a calibrated solar cell. It evaluates the useful resource for concentrating solar application and it is calculated as follow:

$$
I_{\text {direct }}=I_{\text {global }}-I_{\text {diffuse }},
$$




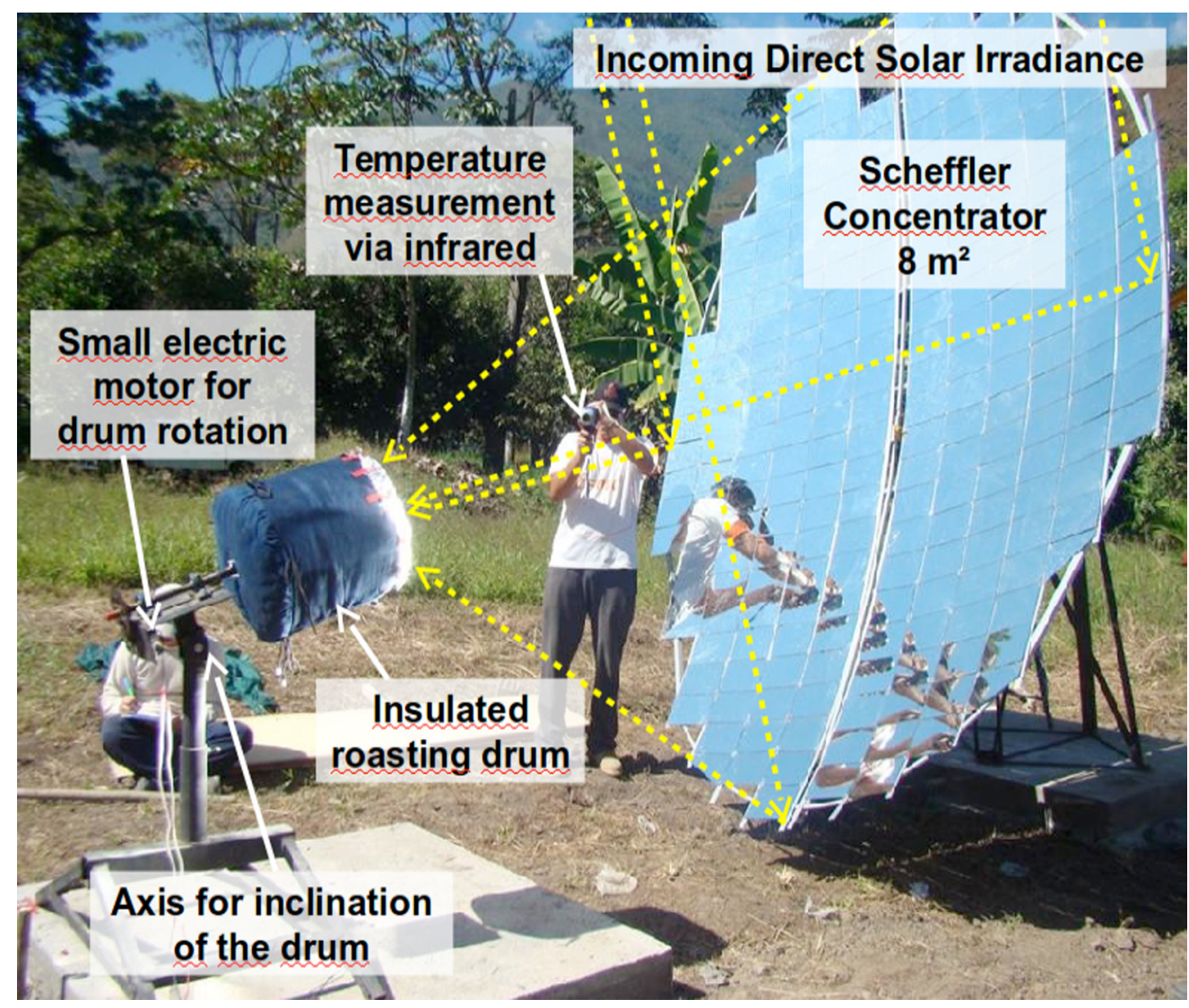

Fig. 1. Photo of the solar roasting technology, showing the path of light towards the focal area.

with $I_{\text {global }}$ as global normal solar irradiance, and $I_{\text {diffuse }}$ as diffuse normal solar irradiance, measured by shading the cell from direct sunlight.

Temperatures are measured with an infrared sensor. We monitored the internal surface temperature of the drum especially during preheating. The cacao temperature is monitored directly in the drum and by extracting a sample in a wooden spoon. To reduce uncertainty, the temperature of various beans is recorded at each measurement point. The standard deviation between the values measured is shown by error bars on the graphics of Figure 2, in the results section. The temperature variability is caused by the different bean colors and sizes and by the infrared sensor which emissivity setting is fixed at 0.95. Initial and final cacao mass are measured, as well as total roast time. Cacao quality is evaluated through physico-chemical and microbiological analysis.

\section{Results}

\subsection{Temperature profile during roasting}

In experiment \#2 on Figure 2 (left), $3 \mathrm{~kg}$ of cacao beans have been roasted under constant solar irradiance of $830 \mathrm{~W} / \mathrm{m}^{2}$. The drum is preheated to $160{ }^{\circ} \mathrm{C}$ in $3.5 \mathrm{~min}$. After $4.5 \mathrm{~min}$, the cacao is poured into the drum. The beans temperature increases, with an initial high heating rate of $8.5^{\circ} \mathrm{C} / \mathrm{min}$, slowing down to a final rate of $1.4^{\circ} \mathrm{C} / \mathrm{min}$.
This can be explained by greater thermal losses at higher temperatures: conduction through the drum walls, convection with the atmosphere and infrared radiation with the environment. Roasting ends after $33 \mathrm{~min}$, when cacao temperature reaches $140{ }^{\circ} \mathrm{C}$.

Experiment \#5 on Figure 2 (right) shows temperatures in the front and at the back of the drum are similar. This confirms the mixing is effective in ensuring an even roast. The bean temperature measured directly in the drum is slightly higher than the one in a spoon, the latter being taken as reference. It can be due to the concentrated solar irradiance falling on the beans in the drum and to decreasing surface temperature of the beans in the spoon. Figure 2 also shows that roasting works with short term clouds (irradiance $<100 \mathrm{~W} / \mathrm{m}^{2}$ ). The inertia of the drum and the cacao mass maintain the system's temperature during several minutes: we measured a drop of $2{ }^{\circ} \mathrm{C}$ in $6 \mathrm{~min}$ during the second cloud.

\subsection{Analysis of the experiments}

To compare the roasting experiments, we calculate a net roasting time at $140{ }^{\circ} \mathrm{C}$ per kilogram of cacao $\Delta t_{\text {roast,net }}$ (min $/ \mathrm{kg})$ defined as follows:

$$
\Delta t_{\text {roast,net }}=\frac{\left(\Delta t_{\text {roast }}-\sum \Delta t_{\text {cloud }}\right)}{m_{\text {cacao }, \mathrm{i}}},
$$



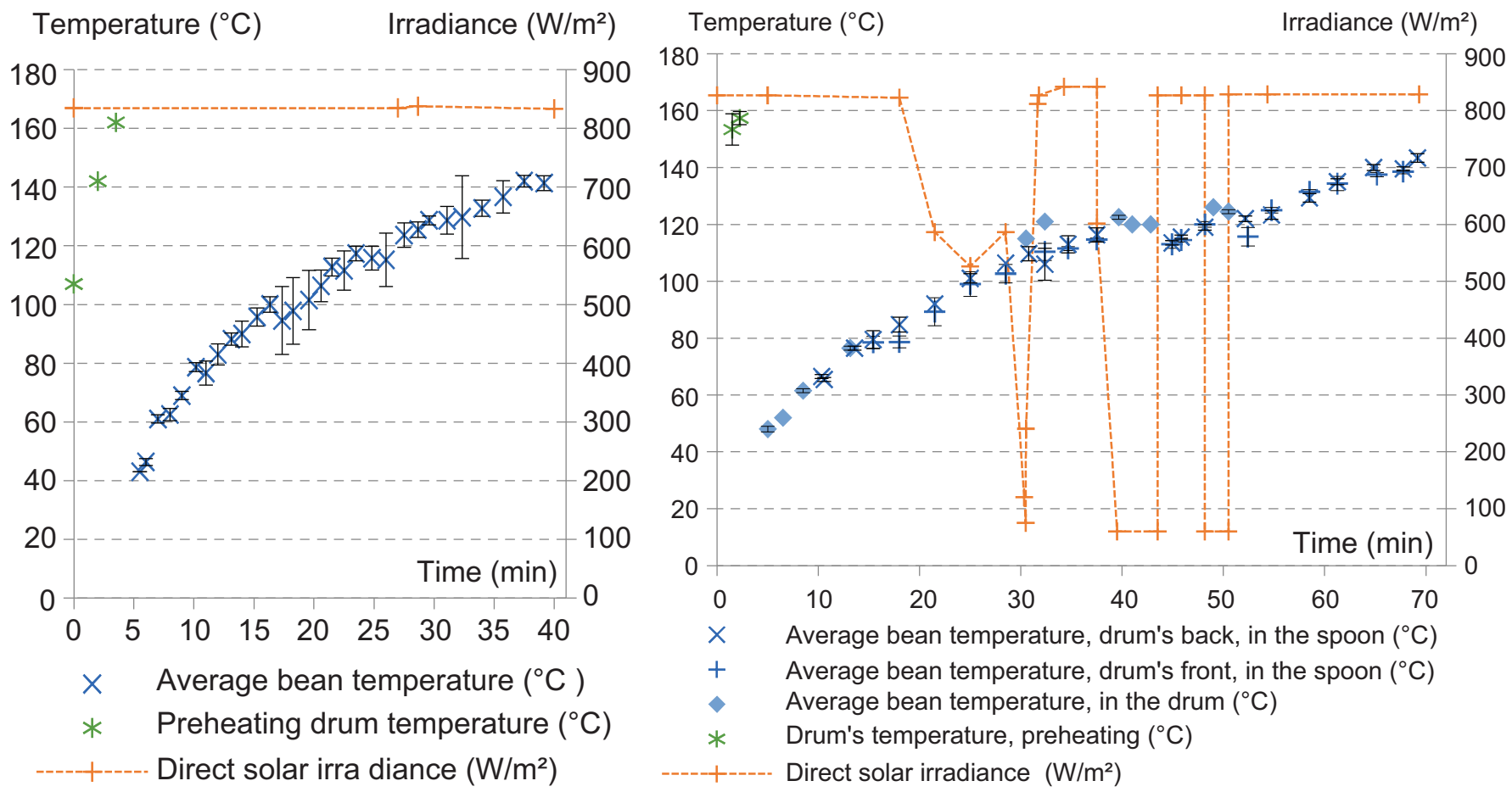

Fig. 2. Left: experiment \#2: evolution of preheating drum temperature and roasting cacao temperature. Good direct solar irradiance; Right: experiment \#5: evolution of cacao temperature in the drum (front and back) and in the spoon. Direct solar irradiance varying with clouds.

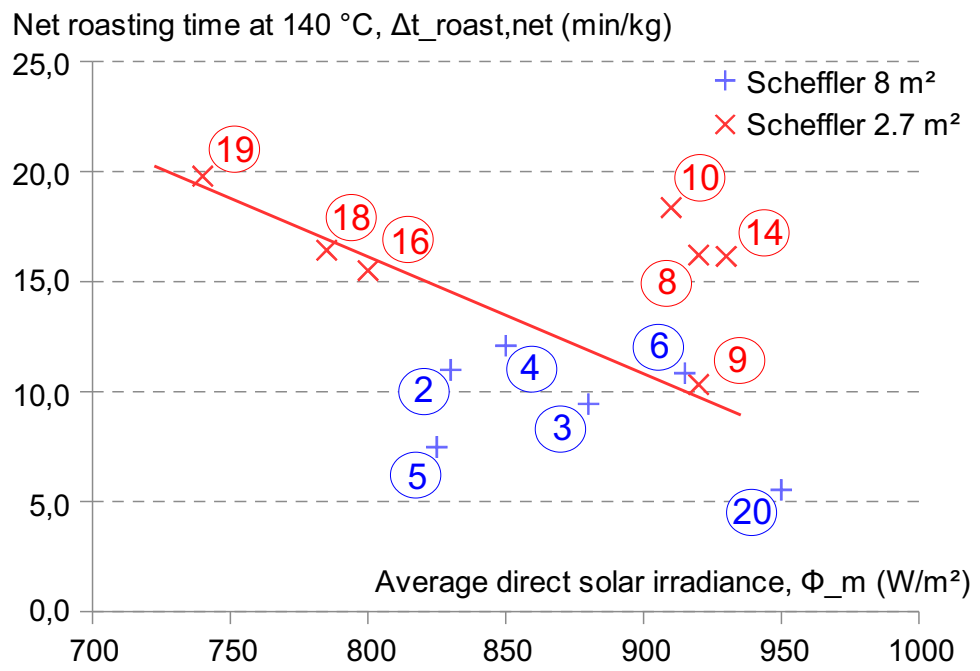

Some key
parameters:
(2) $3 \mathrm{~kg}, 13^{\circ}$
(3) $2 \mathrm{~kg}, 13^{\circ}$
(4) $3 \mathrm{~kg}, 32^{\circ}$
(5) $6 \mathrm{~kg}, 32^{\circ}$
(6) $3 \mathrm{~kg}, 20^{\circ}$
(20) $6 \mathrm{~kg}, 20^{\circ}$
absorptive
(8) no insulation
(9) $2 \mathrm{~kg}, 20^{\circ}$
(10) $1 \mathrm{~kg}, 18 \mathrm{rpm}$
(14) $32^{\circ}$
(16) $2 \mathrm{~kg}, 20^{\circ}$
(18) good focal
point, $1 \mathrm{~kg}$
(19) $2 \mathrm{~kg}, 20^{\circ}$

Fig. 3. Comparison of experiments: net roasting time at $140{ }^{\circ} \mathrm{C}$ per kilogram of cacao versus direct solar irradiance.

with $\Delta t_{\text {roast }}$ as the duration from the cacao input until the temperature curve crosses $140{ }^{\circ} \mathrm{C}, \Sigma \Delta t_{\text {cloud }}$ as the total duration of clouds, $m_{\text {cacao,i }}$ as the initial cacao mass. The average direct solar irradiance $\Phi_{\mathrm{m}}$ is calculated for each experiment.

Figure 3 shows the net roasting time at $140{ }^{\circ} \mathrm{C}$ per kilogram of cacao $\Delta t_{\text {roast,net versus the direct solar }}$ irradiance $\Phi_{\mathrm{mu}}$ for 13 experiments. In the seven additional experiments, the roasting was successful in three cases, but the focal point was badly set up: the additional optical losses make it difficult to compare the results. In the four remaining cases, the temperature did not reach $140{ }^{\circ} \mathrm{C}$, because of too low irradiance or interruption of the solar heating by a big cloud. Table 1 shows the detailed results for a selection of seven experiments: three with the concentrator of $8 \mathrm{~m}^{2}$ and four with the one of $2.7 \mathrm{~m}^{2}$

The experiments $\# 19, \# 18, \# 16$ and $\# 9$ on the $2.7 \mathrm{~m}^{2}$ concentrator show a linear trend between roasting time and solar irradiance. The other experiments performed with the 
Table 1. Selection of seven roasting experiments: summary of main parameters and results.

\begin{tabular}{llllllll}
\hline Test number \# $(-)$ & $\mathbf{2}$ & $\mathbf{5}$ & $\mathbf{2 0}$ & $\mathbf{8}$ & $\mathbf{9}$ & $\mathbf{1 0}$ & $\mathbf{1 4}$ \\
Scheffler concentrator size $\left(\mathbf{m}^{\mathbf{2}}\right)$ & 8 & 8 & 8 & 2.7 & 2.7 & 2.7 & 2.7 \\
Drum volume $(\mathbf{L})$ & 43.5 & 43.5 & 43.5 & 13.5 & 13.5 & 13.5 & 13.5 \\
Average solar irradiance $\boldsymbol{\Phi}_{\mathbf{m}}\left(\mathbf{W} / \mathbf{m}^{\mathbf{2}}\right)$ & 830 & 825 & 950 & 920 & 920 & 910 & 930 \\
Drum properties & & & & & & & \\
Insulation around drum $(-)$ & Yes & Yes & Yes & No & Yes & Yes & Yes \\
Inclination backward $\left({ }^{\circ}\right)$ & 13 & 32 & 20 & 20 & 20 & 14 & 32 \\
Rotational speed (rpm) & 8 & 8 & 18 & 18 & 18 & 18 & 19 \\
Absorptivity (-) & Low & Low & High & High & High & High & High \\
Date (day) November $\mathbf{2 0 1 4}$ & 3 & 3 & 17 & 8 & 8 & 8 & 11 \\
Time (h:min) & $9: 02$ & $11: 15$ & $10: 00$ & $10: 30$ & $11: 45$ & $12: 45$ & $11: 24$ \\
Initial cacao mass $(\mathbf{k g})$ & 3 & 6 & 6 & 2 & 2 & 1 & 2 \\
Final cacao mass $(\mathbf{k g})$ & 2.8 & 5.6 & 5.55 & 1.88 & 1.87 & 0.8 & 1.85 \\
Total clouds duration $(\mathbf{m i n}: \mathbf{s})$ & 0 & $20: 00$ & $16: 48$ & 0 & 0 & $2: 30$ & 0 \\
Final temperature $\left({ }^{\circ} \mathbf{C}\right)$ & 140 & 143 & 158 & 135 & 145 & 153 & 140 \\
Roasting time at $\mathbf{1 4 0}{ }^{\circ} \mathbf{C}(\mathbf{m i n}: \mathbf{s})$ & $32: 58$ & $64: 53$ & $50: 00$ & $32: 25$ & $20: 39$ & $20: 52$ & $32: 18$ \\
Net roasting time at $\mathbf{1 4 0}{ }^{\circ} \mathbf{C ~}(\mathbf{m i n} / \mathbf{k g})$ & $\mathbf{1 1}$ & $\mathbf{7 . 4 8}$ & $\mathbf{5 . 5 3}$ & $\mathbf{1 6 . 2}$ & $\mathbf{1 0 . 3}$ & $\mathbf{1 8 . 4}$ & $\mathbf{1 6 . 1}$ \\
\hline
\end{tabular}

$2.7 \mathrm{~m}^{2}$ concentrator are significantly out of this line. In comparison to the reference experiment $\# 9$ realized with similar solar irradiance, roasting times are increased by:

$-50 \%$ in experiment $\# 8$, because there is no thermal insulation on the drum;

- $50 \%$ in experiment \#14, because the drum inclination is $32^{\circ}$, instead of $20^{\circ}$. Indeed, inclination between $30^{\circ}$ and $60^{\circ}$ lead to the highest convection losses [7];

- $80 \%$ in experiment $\# 10$, because a smaller quantity is roasted. The convection losses are greater, as the movement of the beans change from a "bed" to a "rainfall" mixing.

The roasting time recorded in the literature and given by roasting masters is usually between 10 and $60 \mathrm{~min}$, typically around $30 \mathrm{~min}[8]$. The maximum quantity that can be roasted is defined here for a roasting time of $30 \mathrm{~min}$ with high solar irradiance over $900 \mathrm{~W} / \mathrm{m}^{2}$. With the $8 \mathrm{~m}^{2}$ concentrator, the maximum quantity is $6 \mathrm{~kg}(5 \mathrm{~min} / \mathrm{kg}$ for experiment \#20). With the $2.7 \mathrm{~m}^{2}$ concentrator, up to $3 \mathrm{~kg}$ could be roasted in 30 minutes $(10 \mathrm{~min} / \mathrm{kg}$ for experiment $\# 9$ ). But to fit more than $2 \mathrm{~kg}$ in the small drum, the inclination would become too strong. As observed above, strong inclination gives worse results because of thermal losses. So the maximum of $2 \mathrm{~kg}$ and $20^{\circ}$ of inclination is recommended for the $2.7 \mathrm{~m}^{2}$ Scheffler concentrator.

Experiments with the biggest cacao mass $-6 \mathrm{~kg}$ in \#5 and \#20 - have the smallest roasting time - below $10 \mathrm{~min} /$ $\mathrm{kg}$. Indeed thermal losses are of the same order of magnitude for any quantity of cacao and a higher fill ratio leaves less air for convection in the drum, while a larger surface of beans absorbs light.

The absorptive coating of black enameled steel (small drum with $2.7 \mathrm{~m}^{2}$ concentrator) gives higher optical efficiency than stainless steel (large drum with $8 \mathrm{~m}^{2}$ concentrator). Indeed, the roasting time is not even doubled in the three times smaller roaster, whereas the intrinsic lower thermal efficiency of the small system is expected to more than triple the roasting time. The trend is confirmed by experiment \#20 with the large drum painted in black, which gives the smallest roasting time.

Analysis of cacao paste shows $1.8 \%$ humidity and $53.1 \%$ fat in average. The results comply with the official quality standards. Thequality seems evenhigher (nobiologicalactivity at all) when using the black enameled steel. The higher absorptivity of this material probably increases the internal surface temperature of the drum, which kills all biological activity. Burn traces have been observed on samples roasted with the drum rotating at $10 \mathrm{rpm}$, but not at $20 \mathrm{rpm}$. This encouragestooperatetheroasteratarotationalspeedof $20 \mathrm{rpm}$.

\section{Conclusion}

The experiments show the behavior of the solar roasting technology. Analysis of the results, lead to the following advice to use the roaster with optimal thermal efficiency and product quality:

- put thermal insulation around the drum;

- use absorptive drum walls, like black enameled steel;

- limit inclination to $20^{\circ}$, as a compromise between cacao quantity and thermal efficiency;

- work with maximal cacao quantity:

- $2 \mathrm{~kg}$ with the $2.7 \mathrm{~m}^{2}$ concentrator,

- $6 \mathrm{~kg}$ with the $8 \mathrm{~m}^{2}$ concentrator;

- rotate the drum at $20 \mathrm{rpm}$, to ensure an even roast.

The state of the knowledge enables practical use of the solar roaster in the demonstration plant. Further experimental work and thermal modeling of the solar roaster could consolidate the analysis.

Our thanks to the entire team of the "Grupo de Apoyo al Sector Rural" for its dedication to this project. Thanks to Fondo para la Innovacion, la Ciencia y la Tecnologia (FINCyT), National Peruvian Funding Organization for Innovation, Science and Technology, for financing this study. 


\section{References}

1. Solar Roast Coffee, 2014, http://www.solarroast.com/src about

2. Cocina Solar Mexico, Bicichocosolar, 2015, http://www. cocinasolarmexico.com.mx/crbst_ 7. html

3. Solar Food Processing Network, projects, http://www.solar food.org/projects

4. A. Munir, O. Hensel, W. Scheffler, Sol. Energy 84, 1490, (2010). ISSN: 0038-092X, DOI:10.1016/j.solener.2010.05.011

5. Solare Brücke, The Scheffler reflector, 2015, http://www. solare-bruecke.org
6. NASA Surface Meteorology and Solar Energy, available tables, 2015, https://eosweb.larc.nasa.gov/cgi-bin/sse/grid. cgi? \&num $=108077 \&$ lat $=-13.01 \&$ submit $=$ Submit\&hgt $=100$ \&veg $=17 \&$ sitelev $=\&$ email=skip@larc.nasa.gov $\& p=$ grid id $\& p=$ avg_dnr\&step $=2 \&$ lon $=-72.56$

7. U. Leibfried, J. Ortjohann, J. Sol. Energy Eng. 117, 75, (1995). DOI:10.1115/1.2870873

8. D.M.H. Farah, A.H. Zaibunnisa, Misnawi, Int. Food Res. J. 19, 1355 (2012), http://www.ifrj.upm.edu.my $/ 19 \% 20 \%$ $242804 \% 2429 \% 202012 / 8 \% 20$ IFRJ $\% 2019 \% 20 \% 242804 \% 2429$ \%202012\%20Farah\%20\%2428ifc1\%2429.pdf

Cite this article as: François Veynandt, Juan Pablo Perez Panduro, Jorge Elías Soria Navarro, Miguel Hadzich, Cacao roasting in rural areas of Peru using concentrated solar thermal energy: experimental results, Renew. Energy Environ. Sustain. 1, 8 (2016) 